\title{
ROOT BARRIER AND EXTENSION CASING EFFECTS ON CHINESE HACKBERRY
}

\author{
by Paula J. Peper and Sylvia Mori
}

\begin{abstract}
In California, repairing sidewalk damage associated with tree roots exceeds $\$ 62$ million annually. Efforts to reduce sidewalk damage have provided street tree managers with a variety of root barrier products. In this study, 3 types of root barriers were installed and evaluated to determine whether 1) internal vertical ribs prevented circling roots and 2) root development would be significantly reduced in the top $30 \mathrm{~cm}$ (12 in.) of soil. The 3 barriers tested included 1) a modified production container, partially left in place when planted (extension casing), 2) a commercial product with vertical ribs spaced $15 \mathrm{~cm}$ (6 in.) apart, intended to prevent circling roots, and 3) a commercial product with vertical ribs spaced $12.5 \mathrm{~cm}$ (5 in.) apart. Root diameter, depth, and dry weight were measured for Chinese hackberry (Celtis sinensis) planted and grown for 3 years with and without root barriers. The extension casing reduced root biomass in the top $33 \mathrm{~cm}$ ( $13 \mathrm{in}$.) of soil by $50 \%$ compared to trees without barriers (controls). Mean root diameter of the 6 largest roots outside of the casing was also significantly smaller. Mean root diameters and biomass of controls were similar to those for the 2 commercial barriers. Roots on the trees with root barriers escaped beyond the barrier walls then grew upwards to depths similar to the controls (37 cm [14.5 in.]). Although casings reduced total root biomass and diameter, they appeared to encourage circling root growth. Circling was diminished when commercial barriers with intemal vertical ribs were used. Mean top growth was similar among treatments.
\end{abstract}

Key Words. Root physiology; sidewalk; infrastructure; root biomass; urban forest; urban trees.

In the United States and abroad, public works officials, engineers, street tree managers, and arborists are seeking methods to reduce escalating repair costs associated with root damage to sidewalks, sewers, and buildings (Kopinga 1994; Rolf et al, 1995). Several methods for redirecting root growth away from infrastructure elements have been examined (Wagar and Barker 1993; Barker 1995 a, 1995b; Costello et al. 1997). Additionally, integrated approaches to site design are being discussed and studied, including extensive analysis of such variables as hardscape engineering, soil volumes, soil densities, species selec- tion, tree growth rates and maintenance requirements, and tree proximity to structures and open spaces (Grabosky and Bassuk 1995).

Barriers guide initial root development downward, potentially resulting in a spatial separation between roots and overlying hardscape. The forces generated by radial enlargement of deep roots dissipate throughout a greater volume of soil, consequently delaying the time when sidewalks are adversely affected. Previous studies revealed a 3- to 10-fold reduction in root biomass in the top $30 \mathrm{~cm}$ (12 in.) of soil for Southwestern black cherries (Prunus serotina subsp. virens var. virens) and European hackberries (Celtis australis) grown and out planted in "sleeve" containers (Barker 1995a, 1995b). Similarly, barrier treatments applied to 2 sycamore species (Platanus acerifolia and $P$. wrightii) showed nearly a 50\% reduction in weight of shallow roots compared to control trees (Barker 1992). The barrier treatments included a herbicideimpregnated fabric and a rigid plastic material without internal vertical ribs. However, each barrier type also exhibited a significant number of spiraling roots that could eventually girdle the main root system and impair translocation of sugar to roots. Other studies using chemical and plastic barriers have found deflected roots growing back to the surface after passing under the barrier (Wagar and Barker 1993; Gilman 1995; Costello et al. 1997). Typically, barriers have been installed at approximately $60-\mathrm{cm}$ (24-in.) depths, but 2 previous studies have found significant benefit from barriers that were only $30 \mathrm{~cm}$ (12 in.) deep (Barker 1995 a, 1995b). Beyond these 2 studies, little has been done to determine optimal barrier depths, but such information is important for planting sites with less than optimal conditions (e.g., shallow, dense, and/or poorly aerated soils).

The objectives of this study were to determine 1) if the use of root barriers, installed at a $30-\mathrm{cm}$ (12in.) depth, either as tight-fitting casings surrounding the rootballs or as planting-hole liners, significantly reduced root development in the top $33 \mathrm{~cm}$ (13 in.) 
of soil and 2) if the use of barriers with internal vertical ribs prevented circling roots.

\section{MATERIALS AND METHODS}

The study plot was located at the Solano Urban Forestry Research Area (SUFRA), Suisun City, California. The site receives about $40 \mathrm{~cm}$ (15 in.) of precipitation annually, primarily from October through April. Mean high and low temperatures (30 year) are $21.6^{\circ} \mathrm{C}$ and $9.4^{\circ} \mathrm{C}\left(71^{\circ} \mathrm{F}\right.$ and $\left.49^{\circ} \mathrm{F}\right)$. The soil, classified as Class I of the Yolo Series (Soil Conservation Service, 1977), is an alluvial, well-drained dark brown, silty clay loam without mottling. It has a $\mathrm{pH}$ range of 6.5 to 7.5 and an electrical conductivity for soluble salts of $35 \mathrm{M}$ mhos $/ \mathrm{cm}$ on a dry soil basis.

Fifty-six Chinese hackberry (Celtis sinensis) trees were seed propagated and grown the first 2 years in field rows. Hardwood cuttings were made from these liners and planted in 26-L (7-gal) plastic containers, with extension casings where applicable. Extension casings were custom fabricated from black polyethylene tubing of $0.15 \mathrm{~mm}$ ( $6 \mathrm{mil})$ thickness and were an adaptation of a casing-type barrier used in previous studies (Barker 1994, 1995a, 1995b). Casings measured $26 \mathrm{~cm}$ (10 in.) deep and $18 \mathrm{~cm}$ (7 in.) in diameter. During nursery production, trees were planted in these narrow, bottomless extensions nested on top of the soil medium filling the 26-1 containers (Figure 1). Combining the extension casing and container produced a rootball $54 \mathrm{~cm}$ (2l in.) deep compared to the $31-\mathrm{cm}$ (12-in.) deep rootball produced in the nonextended 26-L containers. New growth on the cuttings was pruned back to a single, dominant leader and grown in these containers for an additional 2 years.

Trees were planted in a randomized complete block design with 4 levels of barrier treatments: 1) control (no barrier or extension casing), (2) DeepRoot ${ }^{\circledR}$ barrier with internal vertical ribs spaced at $15-\mathrm{cm}$ (6-in.) intervals, 3) Tree Root Planter ${ }^{\circledR}$ bar- rier with internal vertical ribs spaced at $12.5-\mathrm{cm}$ (5in.) intervals, and 4) extension casing with no ribs (see Figure 1). Prior to planting, the soil was ripped to a 60-cm (24-in.) depth, then disced and leveled. A tractor-mounted auger (60-cm diameter) was used to drill planting holes. Holes for all treatments were drilled approximately $70 \mathrm{~cm}$ (27.5 in.) deep. Holes for all but the extension casing treatments were then backfilled by hand until reaching a 31-cm (12-in.) depth, and DeepRoot and Tree Root Planter treatments were then installed as planting-hole liners. These consisted of three $60 \times 30 \mathrm{~cm}(24 \times 12 \mathrm{in}$.) panels connected by plastic interlocking strips to form circular planting-hole liners with diameters of approximately $58 \mathrm{~cm}$ (23 in.) (Figure $1 \mathrm{D}, \mathrm{E})$. The barrier edges extended $2.5 \mathrm{~cm}$ ( 1 in.) above ground, with depth below ground at $28 \mathrm{~cm}$ (11 in.). Holes for the extension casing treatment were backfilled to a depth of $54 \mathrm{~cm}(21 \mathrm{in}$.). Trees were then removed from their 26-L (7-gal) containers, planted and staked. Tops of extension casings also extended $2.5 \mathrm{~cm}$ above ground to prevent roots from growing over the barrier. 
Differences in the 2 commercial barriers included anti-lift tabs on the DeepRoot barriers designed to prevent the barrier from lifting as roots grow and expand in diameter beneath it. The Tree Root Planter features notches on the bottom edge of each barrier designed to tear as tree roots enlarge (Peper 1994).

Trees were irrigated for 24 hours every 10 days from April through mid-October each year. In August 1996, 3 years after installation and when the trees were 7 years old and approximately $5 \mathrm{~m}$ (16.4ft) tall, a $1-\mathrm{m}^{3}\left(1.3-\mathrm{yd}^{3}\right)$ pit was excavated manually around each tree to expose roots in the top $33 \mathrm{~cm}$ (13 in.) of soil. First, a trench was dug, forming a perimeter around the $1-\mathrm{m}^{3}$ area to be excavated. Using a 4-tine cultivator, soil was removed from around roots into the trench. For the control and extension casing treatments, we placed circular templates that were $29.1 \mathrm{~cm}$ (11.5 in.) radius from bole centers (same radius as barriers) so that regardless of treatment type, all trees were uniformly excavated from trench edge to barrier/template edge. The same volume of soil was removed from each pit. Once roots were exposed to the $33-\mathrm{cm}$ depth, data were collected as delineated below. The second stage involved excavating from $29.1 \mathrm{~cm}$ from bole center inward to the edge of the original rootballs. Data were collected from this "inside barrier" area.

Data collected included 1) total root dry weight inside barrier, 2) total root dry weight outside barrier, 3) number and length of all roots $(\geq 0.5 \mathrm{~cm}$ [0.2 in.] diameter) horizontally circling the interior of the barriers, 4) root diameter for the 6 largest roots growing $33 \mathrm{~cm}$ from bole center ( $4 \mathrm{~cm}$ [1.5 in.] outside of the barriers), and 5) depth measurement from soil surface at 2 distances from the tree bole $(33 \mathrm{~cm}$ and $66 \mathrm{~cm}$ ) for the 6 largest roots. Outside roots were cut, dried, and sorted into 3 size classes ( $<10 \mathrm{~mm}$, $10-20 \mathrm{~mm}$, and $>20 \mathrm{~mm}$ ).

Soil bulk densities at 2 depths $(10-15 \mathrm{~cm}$ [4-6 in.] and $30-35 \mathrm{~cm}$ [12-14 in.]) were measured to determine if soil compaction had any influence on treatment responses.
Two samples were collected from the outside walls of each excavated pit $(1.3 \mathrm{~m}$ [4.3 ft] from each tree bole) using a soil core sampler with a hammer attachment. Core liner volume was $182 \mathrm{~cm}^{3}\left[11 \mathrm{in.}^{3}\right]$.

Tree responses (stem diameter at $30 \mathrm{~cm}$, tree height, crown volumes) were recorded yearly. Crown volumes were calculated using measurements of crown height, mean crown width, and the geometric formula for the shape of each tree (either horizontal or vertical ellipsoid). Barriers were periodically examined for below-ground breakage and/or disintegration and for roots growing over tops of barriers.

A 2-way analysis of variance (ANOVA) was conducted on all responses. Block-treatment interaction was assumed to be negligible. Tukey's studentized range tests and Dunnett's t-tests were conducted for all possible pairwise comparisons and comparisons of all treatments against a control, respectively $(\alpha=$ 0.05 ). The experiment had 14 replications (blocks), all of which were excavated.

\section{RESULTS Root Growth and Direction}

Mean root dry weights inside and outside of the barriers and outside root diameter on the 6 largest roots

Table 1. Results for all possible pairwise comparisons (Tukey) between all treatment means and for all treatments against the control (Dunnett) were the same, showing significant differences in dry weights and diameter for the extension casing treatment only. Depths of roots from ground surface were measured at 2 distances ( 33 and $66 \mathrm{~cm}$ ) from the tree bole center. Compared to control, barrier and extension casing treatment roots were growing at a deeper level.

\begin{tabular}{llllll}
\hline & $\begin{array}{l}\text { Root dry } \\
\text { weight } \\
\text { inside } \\
\text { barrier } \\
(\mathrm{kg})\end{array}$ & $\begin{array}{l}\text { Root dry } \\
\text { weight } \\
\text { outside } \\
\text { barrier } \\
(\mathrm{kg})\end{array}$ & $\begin{array}{l}\text { Root } \\
\text { diameter } \\
\text { outside } \\
\text { barrier } \\
(\mathrm{cm})\end{array}$ & $\begin{array}{l}\text { Root } \\
\text { depth } \\
\text { at 33-cm } \\
\text { radius } \\
(\mathrm{cm})\end{array}$ & $\begin{array}{l}\text { Root } \\
\text { depth } \\
\text { at 66-cm } \\
\text { Treatius } \\
(\mathrm{cm})\end{array}$ \\
\hline $\begin{array}{l}\text { Control } \\
\text { DeepRoot }\end{array}$ & $0.308 \mathrm{a} *$ & $0.684 \mathrm{a}$ & $1.87 \mathrm{a}$ & $18.54 \mathrm{a}$ & $18.82 \mathrm{a}$ \\
$\begin{array}{c}\text { Tree Root } \\
\text { Planter }\end{array}$ & $0.376 \mathrm{a}$ & $0.616 \mathrm{a}$ & $\begin{array}{l}1.61 \mathrm{a} \\
27.15 \mathrm{~b}\end{array}$ & $\begin{array}{l}23.74 \mathrm{~b} \\
23.25 \mathrm{~b}\end{array}$ \\
$\begin{array}{c}\text { Extension } \\
\text { cabling }\end{array}$ & $0.067 \mathrm{~b}$ & $0.345 \mathrm{~b}$ & $1.04 \mathrm{~b}$ & $24.46 \mathrm{~b}$ & $22.39 \mathrm{~b}$ \\
$\begin{array}{c}\text { Standard } \\
\text { error }\end{array}$ & 0.047 & 0.065 & 0.121 & 0.796 & 1.012 \\
\hline
\end{tabular}

*Treatments followed by the same letter are not significant at $\alpha=0.05$. 


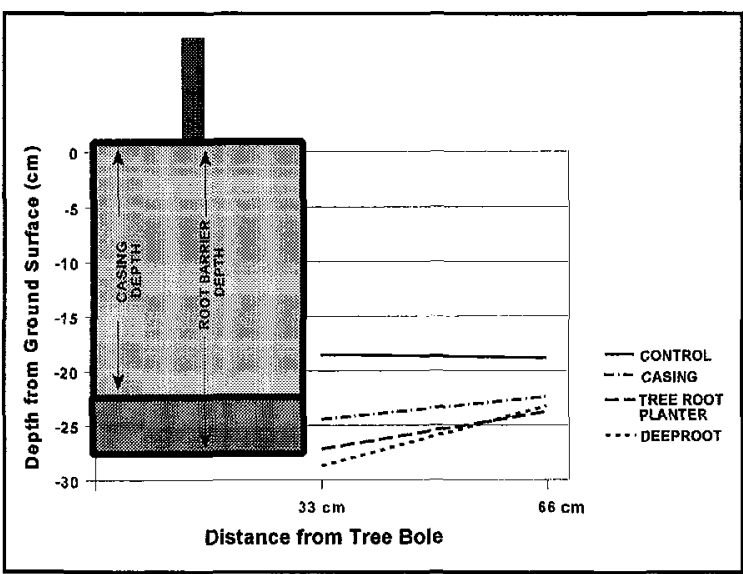

Figure 2. Mean depth of the 6 largest roots growing at 2 distances $(33$ and $66 \mathrm{~cm}$ ) from the tree boles was measured. At $33 \mathrm{~cm}$ from the tree ( $4 \mathrm{~cm}$ outside of the barriers), mean root depth was at or just below the bottoms of the barriers and casings. At $66 \mathrm{~cm}(37 \mathrm{~cm}$ from the barriers), roots for all treatments were ascending toward control root depth.

were less for the extension casing treatment than for the control or the commercial barrier treatments (Table 1). Inside root biomass was reduced nearly 5 fold (67 g [2.4 oz] vs. $308 \mathrm{~g}$ [10.9 oz]), while outside biomass was halved $(345 \mathrm{~g}$ [12.2 oz] vs. $684 \mathrm{~g}$ $\left.\left[\begin{array}{ll}24.1 & \mathrm{oz}\end{array}\right]\right)$. There was no significant difference between control, DeepRoot, and Tree Root Planter treatment root weights or diameters. However, roots were closer to the soil surface for the control than for the 3 barrier treatments (Table 1). At a distance $33 \mathrm{~cm}$ (13 in.) from bole center ( $4 \mathrm{~cm}$ [1.5 in.] outside of barriers), roots essentially grew down to the same depth as the bottom of their respective barriers. Mean root depth was $28.74 \mathrm{~cm}$ (11.3 in.) and $27.2 \mathrm{~cm}$ (10.7 in.), respectively. The extension casing ended at $23 \mathrm{~cm}$ ( 9 in.) below ground, and mean root depth was $24.5 \mathrm{~cm}$ (9.6 in.). At $66 \mathrm{~cm}$ (26 in.) from the tree bole ( $33 \mathrm{~cm}$ away from the barrier), roots grew toward soil surface for all treatments except the control (Figure 2). Controls did not show significant downward root growth. Measured mean root depth of controls was $18.5 \mathrm{~cm}$ (7.3 in.) and $18.8 \mathrm{~cm}(7.4 \mathrm{in}$.) at 33 and $66 \mathrm{~cm}$, respectively. Tree Root Planter and DeepRoot roots changed the most in elevation between the 2 measurement points, ascending $5.5 \mathrm{~cm}$ (2.2 in.) and $3.4 \mathrm{~cm}$ (1.3 in.),

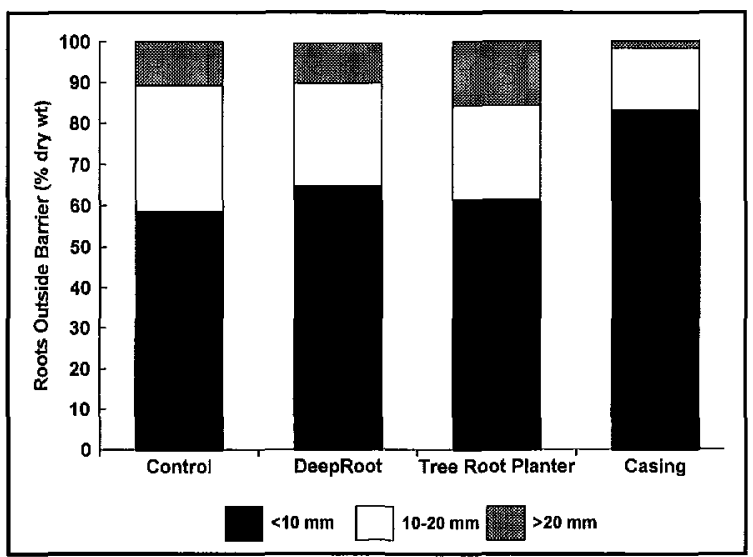

Figure 3. Percentages of the total means of dry weight for each of 3 root diameter classes. Only the casing treatment produced roots with significantly smaller diameters than the control.

whereas extension casing roots ascended $2.1 \mathrm{~cm}$ (0.8 in.). At $66 \mathrm{~cm}$, all 3 treatments were significantly deeper than the control (about $23 \mathrm{~cm}$ [9 in.] below surface level), with no significant difference among the 3 casing/barrier treatments.

Extension casing root diameters were significantly smaller across the 3 size classes measured (Figure 3). Block effect for depth, diameter, and dry weight was not significant.

\section{Circling Roots}

Only 1 root on each of 2 trees in the 2 barrier treatments "jumped" the internal vertical ribs. Counts of roots that began to circle within barriers but were deflected downward by an internal vertical rib varied from 1 to 7 per tree. The extension casing treatment, however, had no internal vertical ribs and circling roots within the casings were prevalent. Ten of the 14 casing replications had large roots circling at least half the circumference of the casing.

\section{Tree Growth}

Differences in stem diameter and total height measurements over the 3-year growth period (2 full growing seasons) were not significant. Tree stems increased in diameter an average of $3.4 \mathrm{~cm}$ (1.3 in.) per year and mean height growth was $0.40 \mathrm{~m}(1.3 \mathrm{ft})$ per year. Crown volumes also showed no significant difference and averaged $11.2 \mathrm{~m}^{3}\left(14.6 \mathrm{yd}^{3}\right)$ before root harvesting in August, 1996. 


\section{Soil Bulk Density}

Bulk densities were not significantly different among treatments. Mean bulk density across treatments was $1.39 \mathrm{~g} / \mathrm{cm}^{3}$ and $1.45 \mathrm{~g} / \mathrm{cm}^{3}$ at the $10-$ and $30-\mathrm{cm}$ core depths, respectively. Although density was greater at the deeper level, both levels were below the $1.50 \mathrm{~g} / \mathrm{cm}^{3}$ critical bulk density level that can limit plant growth (Daddow and Warrington 1983).

\section{Barrier Structural Integrity and Tree Stability}

None of the commercial root barrier panels or connecting devices showed signs of disintegration or rupture. The bottoms of Tree Root Planter barriers have $V$-notches designed to tear as roots mature, thereby reducing the potential of lifting the barrier. Two large roots growing beneath these notches had begun to tear the barriers surrounding 2 trees. None of the commercial barrier panels shifted or uplifted.

Two of the $0.15-\mathrm{cm}$ (6-mil) polyethylene extension casings had partially disintegrated below ground level, but this occurred at some point in time after roots had been deflected downward. No roots grew over the barrier tops that extended $2.5 \mathrm{~cm}$ ( 1 in.) above ground. No trees died or blew over during the 3 years they were installed.

\section{DISCUSSION}

Root biomass and diameter was significantly reduced by the casing treatment but not by the commercial barriers. This result suggests that rootball depth (54 cm [21 in.] vs. $28 \mathrm{~cm}$ [11 in.] for the other treatments) and/or casing treatment affects root growth. Two previous studies conducted at SUFRA on European hackberry (Celtis australis) and Southwestern black cherry (Prunus serotina subsp. virens var. virens) suggest that the casing alone has a greater effect (Barker 1995 a, 1995b). Barker found no significant difference in outside root dry weight for rootballs at depths of 35 and $70 \mathrm{~cm} \mathrm{[14} \mathrm{and} 27.5 \mathrm{in}$.]. However, casing treatments reduced biomass from 3 to 11 -fold for both species. Here, a 54-cm deep rootball with its top half encased reduced Chinese hackberry outside root dry weight by $50 \%$. Whether this effect was due to the casing, the deeper rootball, or both, merits further investigation.

The studies also reveal variation in different species' responses to barrier treatments. The 2 commercial barrier treatments in this study did not significantly reduce outside root biomass, but they did reduce outside biomass of white mulberry (Morus alba) in a prior study (Peper 1998). Extension casings and deep rootballs reduce root dry weight by significantly different amounts depending upon the tree species being tested (Barker 1995a, 1995 b). Such variability in root biomass reduction is a reflection of species variability-the roots of different species having different growth rates and distributions in the soil profile. Species variability (along with soil conditions) will determine the effectiveness of barriers in reducing hardscape damage. Research is needed to document growth and distribution of roots for tree species commonly planted in urban environments.

The casings also reduced root diameters by nearly half. Additional research is needed to study the relationship between root diameter and sidewalk uplifting and breakage, but it appears that the casing treatment might extend the time before damage occurs.

The fact that the casing treatment did not reduce top growth suggests that root development at deeper levels compensated for reduction of biomass in the surface soil horizon. The fact that the trees are still thriving 2 years after all roots in the top $30 \mathrm{~cm}$ of soil were cut and removed supports this concept. However, it should be noted that the casing may be suited only for soils such as the well-drained soil in this study. There are many urban locations where soils are too compacted to plant a rootball this deep.

This is the second study at SUFRA in which Tree Root Planter and DeepRoot treatments have not reduced root diameters (Peper 1998). To better reduce the potential for hardscape damage, barriers would be most effective if they reduced both root mass (or number of roots) and diameter. Results from mulberry (Peper 1998) and hackberry studies indicate that commercial barrier installation at a depth of $28 \mathrm{~cm}$ is not an effective deterrent to surface root growth and distribution. However, both studies indicate that internal vertical ribs do deter circling roots within the barriers. Here, up to 7 roots per tree that had begun to circle were redirected downward by the ribs. The casing treatment lacked internal vertical ribs and circling root growth was common. Ten of the 14 trees had roots that circled at least half of the rootball, creating a potential for structural weakness in the future. 
One concern regarding root barrier use is whether or not they compromise tree stability. There are observational reports of trees blowing over or leaning within 10 to 15 years of planting with barriers (Urban 1994), but little actual research conducted (e.g., excavation of a valid sample size of such trees to determine condition of original nursery stock, surveys of watering regime during tree's establishment period, soil analysis). We did not measure in-ground stability of trees, but none of the trees died or blew over during the 3-year study period or when they were left standing in open pits without staking support for a year after excavation and surface root removal.

Cities that have adopted ordinances regarding root barrier installation for new tree plantings typically require barriers 45 to $60 \mathrm{~cm}$ (18 to 24 in.) deep, not the 30 -cm (12-in.) barriers used here. Testing the $30-\mathrm{cm}$ barriers is a first step toward determining optimal barrier depths. Optimal depth depends on many variables including soil type and density, available nutrients, and watering regimes. The soil at the Solano Urban Forest Research Area has few, if any, qualities that would limit plant growth. The deep, noncompacted, and well-drained silty clay loam is hardly comparable to urban planting sites where the "soil" may be construction rubble, highly compacted, and shallow. However, our studies suggest that species differences may have as much to do with barrier effectiveness or ineffectiveness as soil conditions. Soil conditions at SUFRA were adequate for deep rooting (removal of 6-yearold mulberry and sycamore tree roots at the site required digging to a depth of $1.5 \mathrm{~m}$ [5 ft] with a backhoe), but Chinese hackberry roots returned to surface levels within $0.7 \mathrm{~m}[2.3 \mathrm{ft}]$ of the trees.

The surface roots of some species can grow at deeper levels because they have broader ranges of tolerance to lower levels of oxygen, water, and nutrients. Other species' surface roots, like Raywood ash (Fraxina oxycarpa 'Raywood') and poplar (Populus nigra 'Italica'), do not appear tolerant of change and return to surface levels within 90 to $150 \mathrm{~cm}[35$ to 60 in.] of barriers (Costello et al. 1997). This study indicates that the Chinese hackberry is also less tolerant of change. Certainly, the commercial circling barriers installed at $30-\mathrm{cm}$ depths did not significantly reduce surface root biomass for Chinese hack- berries, even when installed in well-drained, noncompacted soils.

\section{CONCLUSIONS}

The results add to previous evidence that a rootball casing of polyethylene plastic reduces the amount of root biomass and the diameter of individual roots in the surface $33 \mathrm{~cm}$ of soil. Circling roots were prevalent within the casings but were deflected downward by the internal vertical ribs on the 2 commercial barriers. However, commercial barrier installation at a $30-\mathrm{cm}$ depth is inadequate for reducing surface root biomass and diameter.

\section{LITERATURE CITED}

Barker, P.A. 1992. Control of root morphogenesis in two sycamore species, Platanus acerifolia and P. wrightii, pp 567-568. In American Forestry-An Evolving Tradition. Proceedings of the 1992 Society of American Foresters National Convention, Richmond, VA. Society of American Foresters, Bethesda, MD.

Barker, P.A. 1995a. Managed development of tree roots. I. Ultra-deep rootball and root barrier effects on European hackberry. J. Arboric. 21:203-207.

Barker, P.A. 1995b. Managed development of tree roots. II. Ultra-deep rootball and root barrier effects on Southwestern black cherry. J. Arboric. 21:251-258.

Costello, L.R., C.L. Elmore, and S. Steinmaus. 1997. Tree root response to circling root barriers. J. Arboric. 23:211-218.

Daddow, R.L., and G.E. Warrington. 1983. Growthlimiting soil bulk densities as influenced by soil texture. US Forest Service, WSDG Report, WSDG-TN00005. $17 \mathrm{pp}$.

Gilman, E.F., and M.E. Kane. 1990. Root growth of red maple following planting from containers in two different soils. HortScience. 25:527528.

Gilman, E.F. 1995. Root barriers affect root distribution. J. Arboric. 22:151-154.

Goldstein, J., N. Bassuk, P. Lindsey, and J. Urban. 1991. From the ground down. Landscape Architecture. $81: 66-68$.

Grabosky, J., and N. Bassuk. 1995. A new urban tree soil to safely increase rooting volumes under sidewalks. J. Arboric. 21:187-201.

Kopinga, J. 1995. Aspects of the damage to asphalt road pavings caused by tree roots, pp 165-178. In Watson, G.W., and D. Neely (Eds.). The Landscape Below Ground: Proceedings of an International Workshop on Tree Root Development in Urban Soils. International Society of Arboriculture, Champaign, IL. 
McPherson, E.G., and P.J. Peper. (Unpublished data). Survey of California cities: Costs associated with street tree damage to sidewalks and other infrastructure elements. US Forest Service, PSW, Western Center for Urban Forest Research, Davis, CA.

Peper, P.J. 1998. Comparison of root barriers installed at two depths for reduction of white mulberry roots in the soil surface, pp 82-94. In Neely, D., and G.W. Watson (Eds.). The Landscape Below Ground II: Proceedings of an International Workshop on Tree Root Development in Urban Soils. International Society of Arboriculture, Champaign, IL.

Rolf, K, and O. Stal. 1994. Tree roots in sewer systems in Malmo, Sweden. J. Arboric. 20:329-335.

Sealana and Associates. 1994. City of San Jose Sidewalk Survey and Analysis Study. City of San Jose, Department of Streets and Parks, San Jose, CA.

Soil Conservation Service. 1977. Soil survey of Solano County, California. USDA Soil Conservation Service, Davis, CA. 65 pp.

Urban, J.R. 1989. Evaluating urban tree planting practices to determine the limitations of trees in the urban landscape. National Endowment for the Arts, Washington, DC.

Urban, J. R. 1994. Root barriers: An evaluation. Landsc. Arch. 84(9):28-31.

Wagar, J.A. 1985. Reducing surface rooting of trees with control planters and wells. J. Arboric. 11:165-171.

Wagar, J.A., and P.A. Barker. 1983. Tree root damage to sidewalks and curbs. J. Arboric. 9:177-181.

Wagar, J.A., and P.A. Barker. 1993. Effectiveness of three barrier materials for stopping regenerating roots of established trees. J. Arboric. 19:332-338.

Acknowledgements. This project would not have been possible without the assistance of Linda George, who maintained all of the studies installed at the Solano Urban Forest Research Site for 8 years. We thank the Delta Conservation Camp for their valuable assistance with initial excavations. A special thanks goes to the members of "Sergeant Peper's Lonely Roots Club Band"-Linda George, Jason Webber, and Elinor Tretheway-for their meticulous care during final phases of excavation and data collection. Use of trade or firm names in this paper is for reader information and does not imply endorsement by the U.S. Department of Agriculture of any product or service.
Western Center for Urban Forest Research $\&$ Education Pacific Southwest Research Station, USDA Forest Service

c/o Department of Environmental Horticulture

One Shields Avenue

University of California, Davis, CA 95616-8587

Résumé. La réparation des trottoirs endommagés par les racines d'arbres impliquent des déboursés d'au-delà 62 millions de dollars annuellement en Californie. Les efforts en regard de la diminution des dommages aux trottoirs ont permis au gestionnaire d'arbres de disposer d'une variété de barrières racinaires. Dans cette étude, trois types de barrières racinaires ont été installées et étudiées afin de déterminer: 1) si les rainures préviennent le cerclage des racines, et 2) si le développement des racines peut être diminué significativement dans les 30 premiers centimètres de sol. Les trois barrières testées étaient: 1) un contenant de production modifié qui a été laissé partiellement sur place lors de la transplantation, 2) un produit commercial fait de rainures verticales espacées de $15 \mathrm{~cm}$ entre elles dans le but de prévenir le cerclage des racines, et 3) un produit commercial fait de rainures verticales espacées de $12,5 \mathrm{~cm}$ entre elles. Le diamètre des racines, leur profondeur et leur masse sèche ont été mesurés chez du micocoulier chinois (Celtis sinensis) planté et laissé en croissance pendant trois ans avec et sans barrière racinaire. L'emploi de la technique du contenant modifié a permis de réduire la biomasse racinaire dans les 33 premiers centimètres de sol d'un facteur de $50 \%$ comparativement aux arbres sans barrière racinaire. La moyenne en diamètre des six plus grosses racines hors du contenant modifié était aussi significativement plus petite. Le diamètre moyen des racines et la biomasse moyenne des arbres arbres-contrôle étaient similaires à celles des arbres plantés avec les deux produits commerciaux. Les racines des arbres avec des barrières racinaires s'étendaient au-delà des barrières, puis remontaient vers la surface jusqu'à une profondeur similaire à celles des arbres-contrôle $(37 \mathrm{~cm})$. Même si l'emploi de la technique des contenants modifiés a permis de diminuer la masse totale de racines et leur diamètre, elle a semblé favoriser la croissance de racines cerclantes. Le cerclage a été diminué lorsque les barrières commerciales avec des rainures verticales ont été employées. La croissance moyenne de la partie aérienne des arbres était similaire dans tous les cas. 
Zusammenfassung. In Kalifornien betragen die Kosten der Reparatur von Gehsteigen, die von Baumwurzeln verursacht wurden, jährlich $\$ 62$ Millionen. Die Bemühungen, diesen Schaden zu reduzieren, lieferten den Verantwortlichen für die Straflenbäume eine Vielzahl an Produkten zur Begrenzung von Wurzelwachstum. In dieser Studie werden drei Typen von Wurelbarrieren aufgebaut und bewertet um zu bestimmen, ob 1.) inteme vertikale Rippen Dreh- und Würgewurzelbildung verhindern und 2.) das Wurzelwachstum in den oberen 30 $\mathrm{cm}$ deutlich verringert werden kann. Die drei getesteten Barrieren bestanden aus 1.) einem modifizierten Pflanzcontainer, der teilweise nach der Pflanzung verbleibt, 2.) einem kommerziellen Produkt mit vertikalen Rippen im Abstand von $15 \mathrm{~cm}$, um Würgewurzeln zu verhindern und 3.) ein kommerzielles Produkt mit vertikalen Rippen im Abstand von 12,5 cm. Nach der Pflanzung und dem Wachstum von Celtis sinensis für drei Jahre mit und ohne Wurzelbarriere wurden der Wurzeldurchmesser, die Tiefe und das Trockengewicht gemessen. Der modifizierte Pflanzcontainer, der zum Teil in der Erde verbleibt, reduzierte die Biomasse der Wurzeln in den oberen $33 \mathrm{~cm}$ Boden um $50 \%$ im Vergleich zu Bäumen ohne Barriere. Der mittlere Wurezldurchmesser der sechs größten Wurzeln außerhalb des Pflanzcontainers war ebenfalls deutlich geringer. Der mittlere Wurzeldurchmesser und die Biomasse der Kontrollbäume entsprachen denen der beiden anderen Barrieren. Die Wurzeln der Bäume mit Wurzelbarriere unterwuchsen die Barriere und wuchsen dann aufwärts bis zu einer Tiefe von $37 \mathrm{~cm}$, was den Kontrollbäumen entsprach. Obwohl die verbleibenden Pflanzcontainer die totale Wurzelmasse und den Durchmesser reduzierten, schienen sie doch die Bildung von Würgewurzeln anzuregen. Die Entstehung von Würgewurzeln konnte durch kommerzielle Wurzelbarrieren mit internen vertikalen Rippen verhindert werden. Das mittlere Spitzenwachstum war bei allen Pflanzen gleich.
Resumen. En California, la reparación de los daños a las aceras asociados a las raices de los árboles excede 62 millones de dólares anualmente. Los esfuerzos para reducir los daños a las aceras han proporcionado a los gestores del arbolado vial, distintos productos barrera para las raices. En este estudio, fueron instalados y evaluados tres tipos de barreras de raices para determinar: 1) si las costillas verticales internas evitan raíces enrolladas y 2) si el desarrollo de la raíz estuviese significativamente reducido en los $30 \mathrm{~cm}$ superiores (12 pulg) del suelo. Las tres barreras de raíces probadas incluyeron: 1) un contenedor de producción modificado, dejado parcialmente en el lugar en el momento de plantación (ampliación de envoltura "extension casing"), 2) un producto comercial con costillas verticales espaciadas $15 \mathrm{~cm}$ (6 pulg) unas de otras, diseñado para evitar el desarrollo de raices enrolladas y 3) un producto comercial con costillas verticales espaciadas $12,5 \mathrm{~cm}$ ( 5 pulg) unas de otras. Se midieron el diámetro, la profundidad y el peso seco de las raíces para el almez chino (Celtis sinensis) plantado y crecido durante tres años con y $\sin$ barreras de raíces. La ampliación de envoltura redujo la biomasa de raíces de los $33 \mathrm{~cm}$ superiores de suelo, en un $50 \%$ al compararlo con los árboles control, sin barreras. El diámetro medio de seis grandes raíces, afuera de la ampliación de envoltura, fue también significativamente menor. El diámetro medio y la biomasa de las raíces de los controles fueron similares a las de las dos barreras comerciales. Las raíces de los árboles desarrollados con barreras, que escaparon más allá de las paredes de éstas, crecieron hacia arriba hasta una profundidad similar a la de los controles ( $37 \mathrm{~cm}$ [14.5 pulg]). A pesar que las ampliaciones de envoltura redujeron la biomasa total y el diámetro, parece que estimularon el crecimiento de raices enrolladas. Las raíces enrolladas disminuyeron cuando fueron usadas las barreras comerciales con costillas verticales internas. El crecimiento medio de la parte aérea fue similar en los distintos tratamientos. 